\title{
ZWŁOKA KOMORNIKA W UMORZENIU POSTĘPOWANIA EGZEKUCYJNEGO JAKO PODSTAWA ODPOWIEDZIALNOŚCI DYSCYPLINARNEJ
}

\begin{abstract}
Abstrakt: W artykule poświęconym zwłoce komornika w umorzeniu postępowania egzekucyjnego autorka analizuje między innymi wpływ zmiany charakteru umorzenia postępowania z powodu bezczynności wierzyciela na ryzyko wszczęcia postępowania dyscyplinarnego przeciwko komornikowi sądowemu. Rozważa także, w jakim stopniu wpływ na wzrost postępowań dyscyplinarnych ma działanie samych komorników, a na ile ponoszą oni konsekwencje nieprzemyślanych zmian legislacyjnych. Dla przedstawienia tytułowego zagadnienia oprócz omówienia podstaw umorzenia postępowania egzekucyjnego z powodu bezczynności wierzyciela (art. $824 \S 1$ pkt 4 k.p.c.) oraz na jego wniosek (art. 825 pkt 1 k.p.c.) w poprzednim i obowiązującym stanie prawnym, jak również kosztów $\mathrm{z}$ tym związanych. W artykule dodatkowo zestawione zostało podejmowanie przez komornika czynności z nieuzasadnioną zwłoką z przewlekłością postępowania oraz wskutek jego bezczynności.
\end{abstract}

Słowa kluczowe: nieuzasadniona zwłoka, podjęcie przez komornika czynności z nieuzasadnioną zwłoką, umorzenie postępowania egzekucyjnego, postępowanie dyscyplinarne

\section{UWAGI WPROWADZAJĄCE}

Umorzenie postępowania egzekucyjnego jest jedną z czynności orzeczniczych komornika, która (podobnie jak jakakolwiek inna) może stanowić przewinienie dyscyplinarne, a nawet rodzić ewentualną odpowiedzialność odszkodowawczą komornika, jeśli została podjęta z nieuzasadnioną zwłoką.

Samo postępowanie dyscyplinarne jest instrumentem do sprawowania pieczy nad należytym wykonywaniem zawodów prawniczych. Pełni ono funkcję represyjną, ale także ochronną i prewencyjną, mając za zadanie w szczególności piętnowanie działań, które mogłyby podważyć zaufanie do komorników sądowych czy też godzić w godność zawodu zaufania publicznego ${ }^{1}$. Uznanie zatem komornika

1 Szerzej zob. P. Rączka, Odpowiedzialność dyscyplinarna komornika sądowego, „Przegląd Prawa Egzekucyjnego" 2006, nr 12, s. 89-108. 
sądowego za winnego przewinienia dyscyplinarnego stanowi wyraźny sygnał zanegowania poddanego ocenie komisji dyscyplinarnej zachowania z punktu widzenia akceptowanych założeń aksjologicznych ${ }^{2}$.

Podejmowanie przez komornika czynności z nieuzasadnioną zwłoką nie stanowi oczywiście nowej, nieznanej dotąd ustawie formy przewinienia dyscyplinarnego. Taki charakter przewinienia, obecnie uregulowanego w art. 222 pkt 4 ustawy o komornikach sądowych, normowała również w art. 71 pkt 5 ustawa o komornikach sądowych i egzekucji. Można więc zadać pytanie, co się takiego wydarzyło, że w związku z niemal rutynowo podejmowanymi przez komornika sądowego czynnościami polegającymi na umorzeniu postępowania na wniosek wierzyciela bądź też umorzeniu postępowania z urzędu (w wyniku jego bezczynności), wzrosła liczba składanych przez wierzycieli skarg na czynności komornika? ${ }^{3}$

Przyczyn takiego stanu rzeczy można upatrywać w zmianach przepisów, a konkretnie $w$ rozwiązaniach wynikających z przepisów przejściowych, $w$ tym w szczególności z art. 52 ust. 1 i 2 ustawy o kosztach komorniczych. Oczywiście konieczność stosowania przepisów przejściowych ma związek z zastapieniem ustawy z dnia 29 sierpnia 1997 roku o komornikach sądowych ${ }^{4}$ obowiązującymi od 1 stycznia 2019 roku dwiema nowymi ustawami: o kosztach komorniczych ${ }^{5}$ $\mathrm{z}$ dnia 28 lutego oraz o komornikach sądowych ${ }^{6} \mathrm{z}$ dnia 22 marca 2018 roku.

\section{PODEJMOWANIE PRZEZ KOMORNIKA SAZDOWEGO CZYNNOŚCI Z NIEUZASADNIONĄ ZWŁOKĄ JAKO PRZEWINIENIE DYSCYPLINARNE}

Podejmowanie przez komornika sądowego czynności z nieuzasadnioną zwłoką jest jednym z przewinień uzasadniających wszczęcie postępowania dyscyplinarnego (art. 222 pkt 4 ustawy o komornikach sądowych) ${ }^{7}$. Zbliżone rozwiązanie przewidywał art. 71 pkt 5 ustawy o komornikach sądowych i egzekucji, ale

${ }^{2}$ Szerzej zob. J. May, Odpowiedzialność dyscyplinarna komorników, [w:] Modele odpowiedzialności dyscyplinarnej zawodów prawniczych w Polsce i za granica, red. A. Brzezińska-Rawa, J. May, D. Sylwestrzak, Toruń 2018, s. 129-140.

3 Jak wynika $z$ orzecznictwa sądów powszechnych, impulsem do składania skarg było nie tyle umorzenie postępowania egzekucyjnego, ale koszty z tym związane; zob. postanowienie Sądu Rejonowego w Tczewie z 22 marca 2019 roku, I Co 293/19, LEX nr 2638979; postanowienie Sądu Rejonowego Gdańsk-Południe w Gdańsku z 18 kwietnia 2019 roku XII 1 Co 419/2019, LEX nr 2667274

4 Dz.U. z 2018 r. poz. 1309.

5 Dz.U. z 2019 r. poz. 2363.

6 Dz.U. z 2020 r. poz. 121.

7 Słusznie zauważają M. i P. Bieżuńscy, że trudno przyjąć, by w jakiejkolwiek konfiguracji zwłoka mogła być uzasadniona; zob. M. Bieżuński, P. Bieżuński, Ustawa o komornikach sądowych i egzekucji. Komentarz, Warszawa 2010, komentarz do art. 71, teza 6. 
w brzmieniu obowiązującym od 28 grudnia 2007 roku $^{8}$, w pierwotnym bowiem kształcie penalizował podejmowanie przez komornika czynności z rażącą zwłoką9 . Zastąpienie „Zwłoki rażącej” „Zwłoką nieuzasadnioną” wpłynęło na poszerzenie zakresu przedmiotowego tego przewinienia. Niewątpliwie bowiem w praktyce stosowania prawa dużo częściej mamy do czynienia z podejmowaniem czynności z nieuzasadnioną niż rażącą zwłoką. Nieuzasadniona zwłoka komornika nie zawsze będzie kwalifikowana jako rażąca, natomiast każda rażąca zwłoka będzie z pewnością zwłoką nieuzasadnioną.

Rażąca zwłoka jest niewątpliwie kwalifikowaną formą opóźnienia i jednocześnie kwalifikowaną postacią naruszenia prawa. Pojęcie rażącego naruszenia prawa należy do tak zwanych zwrotów niedookreślonych, wymagających wykładni ad causam. W nauce naruszenie prawa o rażącym charakterze oznacza takiego rodzaju naruszenie, w wyniku którego powstają skutki niemożliwe do zaakceptowania z punktu widzenia praworządności. ${ }^{10}$

W uzasadnieniu projektu ustawy nie wyjaśniono przyczyn rezygnacji z „rażącej zwłoki” i zastąpienia jej ,nieuzasadnioną" ${ }^{11}$. Jasne jest jednak, że samo zaistnienie zwłoki nie wystarczy, ponieważ przewinienie dyscyplinarne ma miejsce dopiero wtedy, gdy działanie lub zaniechanie komornika, z którego zwłoka wynikła, było zawinione.

W art. 223 ustawy o komornikach sądowych znajduje się wyraźne odesłanie do odpowiedniego stosowania przepisów k.k. do odpowiedzialności dyscyplinarnej komornika, oczywiście jedynie w zakresie nieuregulowanym w ustawie o komornikach sądowych. $Z$ tego względu dla właściwego pojmowania winy jako podstawy odpowiedzialności dyscyplinarnej należy odwołać się do rozumienia tego pojęcia na gruncie prawa karnego, które wyróżnia winę umyślną oraz winę nieumyślną ${ }^{12}$. Stosownie do art. $9 \S 1$ k.k. czyn zabroniony popełniony jest umyśl-

8 Zob. A. Marciniak, Opinia prawna na temat zasad egzekucyjnego zajęcia wierzytelności $w$ świetle przepisów ustawy z dnia 29 sierpnia 1997 r. o ochronie danych osobowych, „Przegląd Prawa Egzekucyjnego" 2008, nr 1-2, s. 5 n.

9 Rażącą zwłokę jako przesłankę odpowiedzialności odszkodowawczej komornika sadowego przewidywał art. 71, pkt 5 w brzmieniu obowiązującym od 13 listopada 2004 roku (Dz.U. z 2004 r. Nr 236, poz. 2356) do 28 grudnia 2007 roku (Dz.U. z 2007 r. Nr 112, poz. 769). Zob. G. Laszuk, Postęowanie dyscyplinarne $w$ stosunku do komorników (Analiza praktyki w latach 1998-2005), Warszawa 2006, https://iws.gov.pl/wp-content/uploads/2018/08/G-Laszuk-Post\%C4\%99powanie-dyscyplinarne-w-stosunku-do-komornik\%C3\%B3w-2006.pdf (dostęp: 26.11.2020); R. Kowalkowski, Czy komornik musi się obawiać odpowiedzialności dyscyplinarnej, gdy uchybi terminowi $z$ art. 45 a ustawy o komornikach sadowych i egzekucji?, „Problemy Egzekucji” 2001, nr 18, s. 69 n.

10 Por. wyrok Sądu Najwyższego z 20 czerwca 1995 roku, III ARN 22/95, Legalis nr 29365. Szerzej zob. A. Marciniak, Ustawa o komornikach sadowych i egzekucji. Komentarz, Warszawa 2014, komentarz do art. 71.

11 Zob. uzasadnienie do rządowego projektu ustawy o zmianie ustawy o komornikach sądowych i egzekucji oraz niektórych innych ustaw, druk nr 1287 Sejmu RP V kadencji.

12 B. Falkowski, Komentarz do ustawy o komornikach sadowych, [w:] Ustawa o komornikach sadowych. Ustawa o kosztach komorniczych. Komentarz, red. M. Simbierowicz, M. Świtkowski, Warszawa 2019, komentarz do art. 222. 
nie, jeżeli sprawca ma zamiar jego popełnienia, to jest chce go popełnić (dolus directus) albo godzi się na to (dolus eventualis), przewidując możliwość jego popełnienia, natomiast $\mathrm{w}$ wypadku winy nieumyślnej sprawca popełnia czyn wbrew swoim zamiarom na skutek niezachowania ostrożności wymaganej w danych okolicznościach, mimo że możliwość popełnienia tego czynu przewidywał lub mógł przewidzieć (art. $9 \S 2$ k.k.) ${ }^{13}$.

$\mathrm{Z}$ punktu widzenia przewinień unormowanych w art. 222 ustawy o komornikach sądowych każdy stopień winy, w tym również wina nieumyślna, uzasadnia odpowiedzialność dyscyplinarną komornika. Oczywiście odpowiedzialność dyscyplinarną, podobnie jak i odpowiedzialność karną, wyłączają między innymi obrona konieczna czy stan wyższej konieczności ${ }^{14}$.

Przewinieniem dyscyplinarnym jest zatem zawinione podejmowanie przez komornika sądowego czynności z nieuzasadnioną zwłoką. Ustawa o komornikach sądowych nie zawiera definicji tego pojęcia. Wspomniany art. 223 ustawy o komornikach sądowych odsyła, co prawda, do odpowiedniego stosowania przepisów k.k. do odpowiedzialności dyscyplinarnej komornika oraz przepisów k.p.k. do postępowania dyscyplinarnego, jednak ustawy te, w przeciwieństwie do Kodeksu cywilnego, w ogóle nie używają terminu ,zwłoka”. W tym zakresie warto skorzystać raczej z bogatego dorobku nauki prawa cywilnego.

$\mathrm{Na}$ gruncie prawa cywilnego ,zwłoka” rozumiana jest jako kwalifikowana forma opóźnienia, a więc gdy strona ponosi odpowiedzialność za okoliczności, które stanowiły jej przyczynęę ${ }^{15}$, „Zwłoka” $z$ istoty swej zakłada więc opóźnione, zawinione działanie ${ }^{16}$. Zdaniem komentatorów pojęcie zwłoki użyte w art. 222 pkt 4 ustawy o komornikach sądowych należy rozumieć jako szczególny przypadek opóźnienia, kiedy niewykonanie czynności w terminie jest skutkiem zawinionego zachowania ${ }^{17}$.

$\mathrm{Z}$ nieuzasadnioną zwłoką $\mathrm{w}$ podejmowaniu przez komornika czynności mamy do czynienia wówczas, gdy opóźnienie w podejmowaniu czynności nie

13 Szerzej T. Przesławski, [w:] Kodeks karny. Komentarz, red. R. Stefański, Warszawa 2019, komentarz do art. 9; V. Konarska-Wrzosek, Odpowiedzialność karna komornika sądowego, „Przegląd Prawa Egzekucyjnego" 2006, nr 12, s. 71-87.

14 J. Świeczkowski, [w:] Ustawa o komornikach sądowych i egzekucji. Komentarz, red. J. Świeczkowski, Warszawa 2012, komentarz do art. 71, teza 9; A. Marciniak, Ustawa o komornikach..., komentarz do art. 71, teza 5.

15 Zob. wyrok Sądu Najwyższego z 25 maja 2018 roku, I CSK 468/17, Legalis nr 1834482. Por. też A. Rembieliński, [w:] Kodeks cywilny z komentarzem, red. J. Winiarz, Warszawa 1980, s. 471.

16 M. Podrecka, Zaspokojenie interesu wierzyciela przez zastępcze spetnienie świadczenia, „Kwartalnik Prawa Prywatnego" 1999, nr 1, s. 98, przypis 1. Skutek uchybienia terminowi przybiera postać zwłoki lub opóźnienia w zależności od tego czy taki stan rzeczy nastąpił w wyniku okoliczności, za które strona odpowiada. Por. T. Wiśniewski, [w:] G. Bieniek et al., Komentarz do kodeksu cywilnego, ks. 3. Zobowiazania, t. 1-2, Warszawa 2011, s. 784.

17 M. Świeczkowska-Wójcikowska, Komentarz do ustawy o komornikach sądowych, [w:] Ustawa o komornikach sadowych. Ustawa o kosztach komorniczych. Kodeks Etyki Zawodowej Komornika Sądowego. Komentarz, red. J. Świeczkowski, M. Świeczkowska-Wójcikowska, Warszawa 2020, s. 639. 
znajduje uzasadnienia i trwa dłużej niż to konieczne przy uwzględnieniu charakteru czynności oraz terminowości i prawidłowości działań komornika sądowego. Warto też podkreślić, że ocena czy zwłoka komornika sądowego jest nieuzasadniona, a więc czy może stanowić podstawę odpowiedzialności dyscyplinarnej, każdorazowo wymaga zindywidualizowanego podejścia ${ }^{18}$. W takim wypadku nie jest wystarczające zbadanie samej obiektywnie nieuzasadnionej zwłoki w podejmowaniu czynności w postępowaniu egzekucyjnym ${ }^{19}$, konieczne jest przede wszystkim zbadanie okoliczności, które mają znaczenie przy kształtowaniu strony podmiotowej czynu, ale także tych o charakterze przedmiotowym ${ }^{20}$.

\section{NIEUZASADNIONA ZWŁOKA A PRZEWLEKŁOŚĆ POSTĘPOWANIA}

Pojęcie „nieuzasadnionej zwłoki” pojawia się w ustawie z dnia 17 czerwca 2004 roku o skardze na naruszenie prawa strony do rozpoznania sprawy w postępowaniu przygotowawczym prowadzonym lub nadzorowanym przez prokuratora i postępowaniu sądowym bez nieuzasadnionej zwłoki ${ }^{21}$.

Zgodnie $\mathrm{z}$ art. 2 tej ustawy strona może wnieść skargę o stwierdzenie, że w postępowaniu, którego skarga dotyczy, nastąpiło naruszenie jej prawa do rozpoznania sprawy bez nieuzasadnionej zwłoki, jeżeli postępowanie zmierzające do wydania rozstrzygnięcia kończącego postępowanie w sprawie trwa dłużej niż to konieczne dla wyjaśnienia istotnych okoliczności faktycznych i prawnych albo dłużej niż to konieczne do załatwienia sprawy egzekucyjnej lub innej dotyczącej wykonania

18 Ocena tego przewinienia przez komisję dyscyplinarną polega ma polegać między innymi na zbadaniu terminowości i prawidłowości czynności podjętych przez komornika sądowego w celu przeprowadzenia i zakończenia sprawy egzekucyjnej. Por. A. Durda, Ustawa o komornikach sadowych i egzekucji. Komentarz, Warszawa 2016, komentarz do art. 71, teza 5.

$19 \mathrm{~W}$ doktrynie zdania były podzielone, czy przewinieniem dyscyplinarnym było naruszenie terminu instrukcyjnego z uchylonego obecnie art. 45a ustawy o komornikach sądowych i egzekucji, a jeśli tak, to czy wystarczy jednorazowe naruszenie terminu. Według M. i P. Bieżuńskich, komornikowi grozi odpowiedzialność dyscyplinarna $\mathrm{z}$ art. 71 pkt 5, jeśli naruszenie tego terminu jest zawinione. Zob. M. Bieżuński, P. Bieżuński, op. cit., komentarz do art. 45a, teza 1. Zdaniem J. Świeczkowskiego, podstawę odpowiedzialności dyscyplinarnej komornika może stanowić nie jednorazowe, a wielokrotne uchybianie terminom instrukcyjnym, na co wskazuje użyty przez ustawodawcę w art. 71 pkt 5 u.k.s.e. zwrot ,podejmowanie czynności z nieuzasadnioną zwłoką" zamiast „podjęcie czynności z nieuzasadnioną zwłoką”. Zob. J. Świeczkowski, [w:] Ustawa..., komentarz do art. $45 \mathrm{a}$, teza 1.

${ }^{20}$ Nie zachodzą podstawy do odpowiedzialności dyscyplinarnej, jeśli komornik nie podjął z powodu przeszkód prawnych czynności egzekucyjnych niezbędnych dla skutecznego przeprowadzenia egzekucji w przewidzianym w ustawie terminie o charakterze instrukcyjnym. Por. K. Lubiński, Nowelizacja ustawy o komornikach sądowych i egzekucji, „Problemy Egzekucji” 2001, nr 18, s. 5 n.

${ }^{21}$ Dz.U. z 2018 r. poz. 75. 
orzeczenia sądowego (przewlekłość postępowania). Przewlekłość należy oceniać ad causam $^{22}$. Postępowanie zainicjowane wniesieniem skargi na przewlekłość postępowania jest postępowaniem kontrolnym, w którym sąd rozpoznający skargę bada prawidłowość i terminowość czynności podejmowanych przez komornika sądowego w celu przeprowadzenia i zakończenia sprawy egzekucyjnej albo innej sprawy dotyczącej wykonania orzeczenia sądowego ${ }^{23}$. Sam upływ czasu nie świadczy o wystąpieniu stanu przewlekłości. Jako podstawę przewlekłości postępowania postrzega się jego trwanie, ale jest to kryterium oceny warunków, które doprowadziły do przewlekłości, a więc do nadmiernej długości postępowania. Nawet relatywnie długi czas postępowania może być uzasadniony okolicznościami sprawy, a nie nieprawidłowością czynności podejmowanych przez organ ${ }^{24}$.

Prawo strony do rozpatrzenia sprawy bez nieuzasadnionej zwłoki gwarantuje Konstytucja Rzeczypospolitej Polskiej ${ }^{25}$. Zgodnie z jej art. 45 ust. 1 każdy ma prawo do sprawiedliwego i jawnego rozpatrzenia sprawy bez nieuzasadnionej zwłoki przez właściwy, niezależny, bezstronny i niezawisły sąd. Podstawę normatywną prawa do rzetelnego procesu, którego komponentem jest rozpoznanie sprawy bez nieuzasadnionej zwłoki, stanowi również art. 6 Konwencji Europejskiej ${ }^{26}$. Co ważne, prawo do rzetelnego procesu nie ogranicza się wyłącznie do postępowania rozpoznawczego, ale obejmuje swoim zakresem również postępowanie egzekucyjne ${ }^{27}$. Prawo do żądania wykonania świadczenia określonego w tytule wykonawczym w drodze egzekucji składa się na prawo do sądu, stanowiąc istotę efektywnej i przede wszystkim kompletnej ochrony prawnej ${ }^{28}$. Sprawna egzekucja

22 Przewlekłość zachodzi wtedy, gdy czas trwania postępowania przekracza rozsądne granice przy uwzględnieniu terminowości i prawidłowości czynności podjętych przez sąd, charakteru sprawy, stopnia faktycznej i prawnej jej zawiłości, znaczenia dla strony, która wniosła skargę, rozstrzygniętych w niej zagadnień oraz zachowania się stron, a w szczególności strony, która zarzuciła przewlekłość postępowania. Por. uzasadnienie postanowienia Sądu Najwyższego z 2 lipca 2009 roku, III SPP 14/09, Legalis nr 1875153.

${ }^{23}$ Zob. C. Kłak, Rozpatrzenie sprawy bez nieuzasadnionej zwłoki i skarga na przewlekłość postępowania. Zagadnienia wybrane, „Ius Novum” 2011, nr 2, s. 104.

24 Postanowienie Sądu Apelacyjnego w Krakowie z 30 grudnia 2019 roku, II S 18/19, Legalis nr 2480006.

25 Konstytucja Rzeczypospolitej Polskiej z dnia 2 kwietnia 1997 roku, Dz.U. z 1997 r. Nr 78 , poz. 483.

${ }^{26}$ Konwencja o Ochronie Praw Człowieka i Podstawowych Wolności sporządzona w Rzymie z 4 listopada 1950 roku, ratyfikowana przez Polskę 2 października 1993 roku, Dz.U. z 1993 r. Nr 61, poz. $284 \mathrm{ze} \mathrm{zm}$.

27 Jednym z formalnych aspektów prawa do sądu jest załatwienie sprawy bez zbędnej zwłoki (w rozsądnym terminie). Por. S. Cieślak, Formalizm postepowania cywilnego, Warszawa 2008, s. 57.

${ }^{28}$ Prawo do sądu należy rozpatrywać nie tylko w perspektywie możliwości wydania konkretnego rozstrzygnięcia (orzeczenia sądowego), ale i możliwości jego egzekucji. Zadaniem ustawodawcy jest stworzenie takiej normatywnej sytuacji, w której zapewnione będzie nie tylko prawo do sprawiedliwego rozpatrzenia sprawy (wyroku), ale i możliwość jego wykonania. Por. wyrok Trybunału Konstytucyjnego z 27 maja 2008 roku w sprawie P 59/07, OTK-A 2008, nr 4, poz. 64. Zob. też F. Zedler, Sądowe postepowanie egzekucyjne w orzecznictwie Trybunału Konstytucyjnego 
jest elementem efektywnego wymiaru sprawiedliwości ${ }^{29}$. Prawo do rozpoznania sprawy w rozsądnym terminie, bez nieuzasadnionej zwłoki, nie obejmuje zatem jedynie postępowania sądowego do momentu merytorycznego rozpoznania i rozstrzygnięcia sprawy cywilnej, ale rozciąga się także na postępowanie egzekucyjne i obejmuje okres do czasu definitywnego zaspokojenia roszczeń wierzyciela ${ }^{30}$.

Zakwalifikowanie podejmowania przez komornika czynności z nieuzasadnioną zwłoką jako przewinienia dyscyplinarnego (art. 222 pkt 4 ustawy o komornikach sądowych) ma na celu wyeliminowanie możliwości wystąpienia przewlekłości postępowania z winy komornika. Unormowanie to ma także dyscyplinować komorników do przestrzegania określonych przez ustawodawcę terminów ${ }^{31}$. Przewlekłość postępowania objawiająca się $\mathrm{w}$ niepodejmowaniu czynności procesowych w ogóle bądź też w podejmowaniu ich w sposób przewlekły godzi w prawa stron. Skoro ustawodawca kwalifikuje podejmowanie przez komornika czynności z nieuzasadnioną zwłoką jako delikt dyscyplinarny, to warto się zastanowić, czy odwołanie do „nieuzasadnionej zwłoki” w rozumieniu ustawy z dnia 17 czerwca 2004 roku o skardze na przewlekłość postępowania będzie pomocne w ustaleniu zakresu pojęciowego analizowanego przewinienia dyscyplinarnego oraz jaki wpływ na odpowiedzialność dyscyplinarną komornika ma uwzględnienie skargi na przewlekłość postępowania.

Przede wszystkim podejmowania przez komornika czynności z nieuzasadnioną zwłoką nie należy utożsamiać z przewlekłością postępowania egzekucyjnego, ponieważ w wyniku nieuzasadnionej zwłoki w podjęciu czynności może, ale nie musi, dojść do przewlekłości postępowania. Warto też podkreślić, że nawet stwierdzenie takiej przewlekłości nie ma wpływu na ocenę tego, czy doszło do przewinienia dyscyplinarnego, co wynika z odmiennych przesłanek będących podstawą zarówno do uwzględnienia skargi na przewlekłość postępowania, jak i odpowiedzialności komornika za przewinienie dyscyplinarne. Do uwzględnienia skargi na przewlekłość postępowania wystarczy bowiem obiektywne naruszenie prawa strony do rozpoznania sprawy w rozsądnym terminie, podczas gdy odpowiedzialność dyscyplinarna komornika jest oparta na zasadzie winy. Wskazuje na to wyraźnie brzmienie art. 222 ustawy o komornikach sądowych, który jako przewinienie dyscyplinarne kwalifikuje zawinione działanie lub zaniechanie ze strony komornika ${ }^{32}$.

w latach 1985-2008, [w:] Orzecznictwo Trybunalu Konstytucyjnego a kodeks postępowania cywilnego, red. T. Ereciński, K. Weitz, Warszawa 2010, s. 80 n.

29 Szerzej zob. J. Derlatka, Zasada sprawnej egzekucji sądowej jest elementem efektywnego wymiaru sprawiedliwości, „Zeszyty Naukowe Katolickiego Uniwersytetu Lubelskiego Jana Pawła II" 2017, nr 3, s. 119 n.

30 Wyroki Trybunału Konstytucyjnego z 24 lutego 2003 roku, K 28/02, OTK-A 2003, nr 2, poz. 13; oraz z 4 listopada 2010 roku, K 19/06, OTK-A 2010, nr 9, poz. 96.

31 B. Falkowski, op. cit., komentarz do art. 222, teza 6.

32 Podobnie jego poprzednik, art. 71 ustawy o komornikach sądowych i egzekucji, również przewidywał odpowiedzialność dyscyplinarną za „za zawinione działania lub zaniechania” komornika. 
Przewlekłość postępowania w ujęciu ustawy z dnia 17 czerwca 2004 roku $^{33}$ jest kategorią obiektywną, niezależną od winy organu prowadzącego postępowanie (art. 2 ustawy). Z tego powodu uwzględnienie skargi na przewlekłość postępowania nie może stanowić prejudykatu w postępowaniu dyscyplinarnym, w którym konieczne jest zbadanie subiektywnej strony działania (zaniechania) komornika sądowego, co jest kluczowe dla oceny możliwości przypisania mu winy ${ }^{34}$. Do przesądzenia odpowiedzialności dyscyplinarnej komornika nie wystarczy więc na przykład samo stwierdzenie przewlekłości postępowania, nawet w stopniu uzasadniającym uwzględnienie skargi na naruszenie prawa strony do rozpoznania sprawy bez nieuzasadnionej zwłoki.

\section{UMORZENIE POSTĘPOWANIA EGZEKUCYJNEGO NA WNIOSEK WIERZYCIELA (ART. 825 PKT 1 K.P.C.) ORAZ WSKUTEK JEGO BEZCZYNNOŚCI (ART. 824 § 1 PKT 4 K.P.C.) I KOSZTY Z TYM ZWIĄZANE — W POPRZEDNIM ORAZ OBOWIĄZUJĄCYM STANIE PRAWNYM}

Umorzenie postępowania egzekucyjnego następuje, gdy zaistniała przeszkoda o charakterze trwałym, której usunięcie nie jest możliwe ${ }^{35} \mathrm{z}$ uwagi na długotrwałość postępowania lub z innych przyczyn ${ }^{36}$. Umorzenie postępowania powoduje uchylenie dokonanych czynności egzekucyjnych, ale nie uniemożliwia ponownego wszczęcia postępowania, o ile tylko zachodzi dopuszczalność egzekucji sądowej (art. 826 k.p.c. $)^{37}$.

Po uchyleniu art. 823 k.p.c., który stanowił podstawę do umorzenia postępowania z mocy samego prawa, umorzenie postępowania egzekucyjnego może nastąpić $\mathrm{z}$ mocy postanowienia organu egzekucyjnego (z urzędu — art. 824 k.p.c. lub na wniosek — art. 825 k.p.c.) bądź też z mocy postanowienia sądu (wydanego

33 Dz.U. z 2018 r. poz. 75.

34 Por. M. Klonowski, [w:] Ustawa o komornikach sadowych. Ustawa o kosztach komorniczych. Komentarz, red. R. Reiwer, Warszawa 2019, komentarz do art. 222, teza 10.

35 E. Wengerek, Sadowe postępowanie egzekucyjne w sprawach cywilnych, Warszawa 1970, s. 109 n.; K. Korzan, Sadowe postępowanie zabezpieczajace i egzekucyjne w sprawach cywilnych, Warszawa 1986, s. 245 n.

36 J. Jagieła, Wybrane zagadnienia dotyczace zawieszenia i umorzenia postepowania egzekucyjnego, „Problemy Egzekucji” 1999, nr 2, s. 71 n.

37 Zob. E. Wengerek, Saqdowe..., s. 109; Z. Szczurek, [w:] Egzekucja sądowa w prawie polskim, red. Z. Szczurek, Sopot 2015, s. 369. Jak trafnie zauważa J. Jagieła, po umorzeniu właściwego postępowania egzekucyjnego mogą, a niekiedy nawet muszą, być dokonywane jeszcze inne czynności o różnym charakterze wiążące się z umorzonym postępowaniem, na przykład uchylenie zajęcia ruchomości czy uchylenie dozoru zajętych ruchomości. Zob. idem, Zasady egzekwowania kosztów postępowania egzekucyjnego ustalonych przez komornika sądowego, „Przegląd Sądowy” 2015 , nr 5, s. 35 n. 
po rozpoznaniu skargi na czynności komornika lub zażalenia na postanowienie sądu $)^{38}$. Umorzenie postępowania egzekucyjnego mogą uzasadniać przyczyny zależne lub niezależne od woli wierzyciela ${ }^{39}$. Właśnie do pierwszej z wymienionych kategorii należy zarówno umorzenie postępowania egzekucyjnego na wniosek wierzyciela (art. 825 pkt 1 k.p.c.), jak i umorzenie wskutek jego bezczynności (art. $824 \S 1$ pkt 4 k.p.c.).

Ustawą z dnia 10 lipca 2015 roku o zmianie ustawy — Kodeks cywilny, ustawy - Kodeks postępowania cywilnego oraz niektórych innych ustaw ${ }^{40}$ wprowadzony został do k.p.c. art. $824 \S 1$ pkt 4, zgodnie z którym postępowanie umarza się w całości lub części z urzędu, jeżeli wierzyciel w ciągu sześciu miesięcy nie dokonał czynności potrzebnej do dalszego prowadzenia postępowania lub nie zażądał podjęcia zawieszonego postępowania. Ta sama ustawa ${ }^{41}$ uchyliła art. 823 k.p.c., który od 1 stycznia 1965 roku, czyli od wejścia w życie k.p.c., stanowił podstawę do umorzenia postępowania egzekucyjnego z mocy samego prawa, jeżeli wierzyciel $\mathrm{w}$ ciągu roku nie dokonał czynności potrzebnej do dalszego prowadzenia postępowania lub nie zażądał podjęcia zawieszonego postępowania ${ }^{42}$. W uzasadnieniu projektu ustawy wyjaśniano, że

instytucja umorzenia postępowania egzekucyjnego z mocy prawa na podstawie art. 823 k.p.c. jest w praktyce źródłem wielu wątpliwości. Proponuje się zatem uchylenie tego przepisu. »Bezczynność wierzyciela« będzie stanowiła przesłankę umorzenia postępowania $\mathrm{w}$ drodze postanowienia wydawanego z urzędu przez organ egzekucyjny (projektowany art. $824 \S 1$ pkt 4 k.p.c.). Jednocześnie przewidziano skrócenie (do sześciu miesięcy) okresu, z upływem którego będzie wydawane postanowienie o umorzeniu postępowania. Czas ten jest zwykle wystarczający do podjęcia przez wierzyciela czynności koniecznych do dalszego prowadzenia postępowania. Projektowany przepis uwzględnia też potrzebę ochrony interesów dłużnika, który nie powinien zbyt długo pozostawać w niepewności co do swojej sytuacji prawnej i stanu swojego majątku (na przykład gdy składniki majątkowe są zajęte) $)^{43}$.

38 A. Marciniak, Sądowe postępowanie egzekucyjne, Warszawa 2013, s. 263 n.

39 E. Wengerek, Sądowe..., s. 109. Wola wierzyciela może być wyrażona w sposób wyraźny poprzez złożenie wniosku o umorzenie postępowania egzekucyjnego lub dorozumiany w wyniku bezczynności, a więc nie podjęcia przez wierzyciela czynności niezbędnej do dalszego prowadzenia postępowania egzekucyjnego. Zob. K. Korzan, op. cit., s. 246.

40 Ustawa o zmianie ustawy - Kodeks cywilny, ustawy - Kodeks postępowania cywilnego oraz niektórych innych ustaw z dnia 10 lipca 2015 roku, Dz.U. z 2015 r. poz. 1311.

41 Dz.U. z 2015 r. poz. 1311.

42 Jak zauważa M. Uliasz, art. $824 \S 1$ pkt 1 k.p.c. ma zastosowanie tylko do postępowań wszczętych po wejściu w życie tej ustawy, czyli od 8 września 2016 roku (art. 21 ust. 1 tej ustawy). Natomiast w sprawach egzekucyjnych wszczętych przed tym dniem umorzenie postępowania egzekucyjnego następuje z mocy prawa na podstawie art. 823 k.p.c. Zob. M. Uliasz, Komentarz do ustawy o kosztach komorniczych, [w:] Ustawa o komornikach sadowych. Ustawa o kosztach komorniczych. Kodeks Etyki Zawodowej Komornika Sadowego. Komentarz, red. J. Świeczkowski, M. Świeczkowska-Wójcikowska, Warszawa 2020, s. 1268.

43 Zob. uzasadnienie projektu ustawy - Kodeks postępowania cywilnego oraz niektórych innych ustaw, Sejm RP VIII kadencji, druk sejmowy nr 3137. 
Umorzenie postępowania egzekucyjnego na podstawie art. $824 \S 1$ pkt 4 k.p.c. ma zupełnie inny charakter niż uchylony art. 823 k.p.c. ${ }^{44}$ Obowiązujący od 8 września 2016 roku $^{45}$ art. $824 \S 1$ pkt 4 k.p.c. przewiduje obligatoryjne umorzenie postępowania $\mathrm{z}$ urzędu wymagające wydania przez organ egzekucyjny postanowienia, podczas gdy umorzenie $\mathrm{z}$ mocy samego prawa następowało w wyniku spełnienia ustawowych przesłanek określonych w art. 823 k.p.c., czyli upływu rocznego terminu bezczynności wierzyciela, który był liczony od dnia dokonania ostatniej czynności egzekucyjnej, a w razie zawieszenia postępowania — od ustania przyczyny zawieszenia ${ }^{46}$. Umorzenie postępowania z mocy prawa oznaczało, że nie było potrzebne wydanie przez organ egzekucyjny postanowienia o umorzeniu postępowania ${ }^{47}$. Przyczyną tego ostatniego z mocy prawa była bowiem bezczynność wierzyciela, polegająca na niepodejmowaniu przez niego w ciągu roku czynności potrzebnej do dalszego prowadzenia egzekucji, a więc umorzenie $\mathrm{w}$ takim wypadku następowało ex lege ${ }^{48}$. Umorzenie postępowania z mocy prawa stanowiło sankcję dla wierzyciela, który nie współdziałał z organem egzekucyjnym, pozostając bezczynnym. Rozwiązanie to miało równocześnie na celu ochronę dłużnika przed ograniczaniem go w rozporządzaniu przedmiotem objętym egzekucją ${ }^{49}$. Wierzyciel lub dłużnik mogli jednak uzyskać zaświadczenie o umorzeniu postępowania (art. $827 \S 2$ k.p.c.) $)^{50}$.

Skutki prawne umorzenia postępowania $\mathrm{z}$ mocy samego prawa następowały z upływem roku od dnia dokonania ostatniej czynności egzekucyjnej, a w razie zawieszenia postępowania — od ustania przyczyny zawieszenia (art. $165 \S 1$ k.p.c. W zw. z art. 112 k.c. $)^{51}$. Natomiast skutki prawne postanowienia o umorzeniu postępowania egzekucyjnego na podstawie art. $824 \S 1$ pkt 4 k.p.c. biegną dopiero od wydania, a następnie od uprawomocnienia tego postanowienia. Od momentu

${ }^{44}$ Szerzej na temat umorzenia ex lege zob. J. Świeczkowski, Umorzenie postepowania egzekucyjnego na podstawie art. 823 k.p.c., „Gdańskie Studia Prawnicze” 2011, nr 2, s. 453-470.

45 Dz.U. z 2015 r. poz. 1311.

46 Szerzej zob. E. Wengerek, Postępowanie zabezpieczajace i egzekucyjne. Komentarz, Warszawa 1972, s. 231 n.; J. Jagieła, Wybrane..., s. 74 n.

47 Wydanie postanowienia o umorzeniu postępowania egzekucyjnego, które uległo umorzeniu $\mathrm{z}$ mocy prawa, choć zbędne i niepożądane, jest w istocie jedynie postanowieniem stwierdzającym to umorzenie. Ma więc ono charakter deklaratoryjny. Zob. uchwała Sądu Najwyższego z 16 maja 1996 roku, III CZP 44/96, Legalis nr 29990.

48 Szerzej zob. A. Olaś, Umorzenie procesu cywilnego, Warszawa 2016, s. 428 n.

49 E. Wengerek, Postępowanie..., s. 231.

50 Z. Świeboda, Postępowanie zabezpieczające i egzekucyjne. Komentarz do części drugiej Kodeksu postępowania cywilnego, Warszawa 1994, s. 107.

${ }^{51}$ Umorzenie postępowania z mocy prawa oznacza, że nie jest potrzebne wydanie przez organ egzekucyjny postanowienia o umorzeniu postępowania. Umorzenie to nie traci tego charakteru na skutek późniejszego wydania przez sąd postanowienia o umorzeniu postępowania. Wydane przez sąd postanowienie o umorzeniu postępowania egzekucyjnego, które uległo umorzeniu z mocy prawa, jest w istocie postanowieniem stwierdzającym to umorzenie. Ma więc ono charakter deklaratoryjny. Zob. uchwała Sądu Najwyższego z 16 maja 1996 roku, III CZP 44/96, Legalis nr 29990. 
wprowadzenia przepis art. $824 \S 1$ pkt 4 k.p.c. nadal obowiązuje w niezmienionym brzmieniu, jednak jego znaczenie wzrosło od 1 stycznia 2019 roku, kiedy to weszła w życie ustawa z dnia 28 lutego 2018 roku o kosztach komorniczych ${ }^{52}$.

$\mathrm{Z}$ kolei umorzenie postępowania egzekucyjnego na podstawie art. $825 \mathrm{pkt} 1$ k.p.c. następuje $\mathrm{z}$ inicjatywy wierzyciela. Co do zasady wierzyciel jako dysponent postępowania egzekucyjnego może zawsze wnioskować o jego umorzenie ${ }^{53}$, co stanowi wyrazisty przejaw silnie obowiązującej w postępowaniu egzekucyjnym zasady dyspozycyjności ${ }^{54}$. Ustawodawca nie przewidział żadnych dodatkowych wymogów warunkujących uwzględnienie takiego wniosku ${ }^{55}$. Wniosek wierzyciela jest wiążący dla organu egzekucyjnego i nie podlega żadnej kontroli tego organu z punktu widzenia jego zasadności i celowości ${ }^{56}$. $Z$ tego względu bez znaczenia są przyczyny, które zaważyły na decyzji wierzyciela, skoro decyzji tej nie musi uzasadniać57.

W każdym orzeczeniu kończącym postępowanie, a takim niewątpliwie jest postanowienie o umorzeniu postępowania, musi znaleźć się rozstrzygnięcie o kosztach. Ustawa z dnia 28 lutego 2018 roku o kosztach komorniczych ${ }^{58}$ wprowadziła nowe zasady rozdziału kosztów postępowania egzekucyjnego. Przed 1 stycznia 2019 roku w sprawach o egzekucję świadczeń pieniężnych w przypadku umorzenia postępowania egzekucyjnego na wniosek wierzyciela (art. 825 pkt 1 k.p.c.) oraz w wyniku jego bezczynności na podstawie art. $824 \S 1$ pkt 4 k.p.c. opłatę stosunkową komornik pobierał od dłużnika, obecnie zaś opłata ta obciąża wierzyciela. Stosownie do art. 29 ust. 1 ustawy o kosztach komorniczych, w razie umorzenia postępowania egzekucyjnego na wniosek wierzyciela albo na podstawie art. $824 \S 1$ pkt 4 k.p.c. wierzyciela obciąża opłata stosunkowa w wysokości $5 \%$ wartości świadczenia pozostałego do wyegzekwowania. Zastosowanie opłaty

52 Dz.U. z 2019 r. poz. 2363.

53 Jedyne ograniczenie $\mathrm{w}$ tym zakresie przewiduje się $\mathrm{w}$ sprawach, w których egzekucję wszczęto z urzędu lub na żądanie uprawnionego organu, wówczas wniosek wierzyciela o umorzenie postępowania wymaga zgody sądu lub uprawnionego organu, który zażądał wszczęcia egzekucji (art. 825 pkt 1 in fine k.p.c.).

54 Wyrok Sądu Apelacyjnego we Wrocławiu z 25 maja 2016 roku, I ACa 433/16, LEX nr 2274324.

55 O. Marcewicz, [w:] Kodeks postepowania cywilnego. Koszty sadowe w sprawach cywilnych. Dochodzenie roszczeń w postępowaniu grupowym. Przepisy przejściowe. Komentarz do zmian, t. 2, red. T. Zembrzuski, Warszawa 2020, s. 1551.

56 Wyrok Sądu Apelacyjnego we Wrocławiu z 25 maja 2016 roku, I ACa 433/16, LEX nr 2274324.

57 Z. Merchel, Opłaty egzekucyjne w sprawach eksmisyjnych, „Problemy Egzekucji” 2001, $\mathrm{nr}$ 14, s. 57. Zob. też J. Świeczkowski, Wystuchanie stron przed zawieszeniem lub umorzeniem postępowania egzekucyjnego, „Problemy Egzekucji” 2001, nr 13, s. 36; O. Marcewicz, E. Streit-Browarna, Zasada obowiazkowego wszczęcia administracyjnego postępowania egzekucyjnego a zasada dyspozytywności w sądowym postępowaniu egzekucyjnym - ujęcie prawnoporównawcze, „Studia Iurudica Lublinensia” 2016, nr 1, s. 302.

58 Dz.U. z 2019 r. poz. 2363. 
stosunkowej obejmuje dwie wymienione w przepisie sytuacje. Pierwsza z nich dotyczy obligatoryjnego umorzenia postępowania egzekucyjnego w całości lub części na wniosek wierzyciela (art. 825 pkt 1 k.p.c.). Druga natomiast odnosi się do bezczynności wierzyciela, który w ciągu sześciu miesięcy nie dokonał czynności potrzebnej do dalszego prowadzenia postępowania lub nie zażądał podjęcia zawieszonego postępowania (art. $824 \S 1$ pkt 4 k.p.c.) ${ }^{59}$. Rozwiązanie to zasadniczo różni się więc od poprzednich unormowań, ponieważ uprzednio koszt opłaty stosunkowej w wysokości 5\% wartości świadczenia pozostałego do wyegzekwowania, jednak nie niższej niż $1 / 20$ i nie wyższej niż dziesięciokrotna wysokość przeciętnego wynagrodzenia miesięcznego, ponosił dłużnik (art. 49 ust. 2 ustawy o komornikach sądowych i egzekucji) ${ }^{60}$.

Wątpliwości, jakie przepisy należy stosować, w tym zwłaszcza, od kogo i w jakiej wysokości pobrać opłatę stosunkową, zrodziły się w odniesieniu do postępowań prowadzonych na przełomie lat 2018 i 2019, kiedy to postępowanie egzekucyjne było wszczynane w czasie obowiązywania ustawy o komornikach sądowych i egzekucji. Co istotne, jeszcze w czasie obowiązywania tej ustawy zachodziły podstawy do umorzenia postępowania egzekucyjnego, a komornik umorzył postępowanie dopiero po 1 stycznia 2019 roku, już po wejściu w życie nowej ustawy o kosztach komorniczych.

Zmiana charakteru umorzenia postępowania polegająca na uchyleniu art. 823 k.p.c. normującego umorzenie postępowania z mocy samego prawa i zastąpieniu go umorzeniem postępowania z urzędu (art. $824 \S 1$ pkt 4 k.p.c.) sprawiła, że wyłącznie od daty wydania przez komornika postanowienia o umorzeniu postępowania egzekucyjnego zależy, która ze stron tego postępowania zostanie obciążona kosztami - dłużnik (art. 49 ust. 2 ustawy o komornikach sądowych i egzekucji) czy wierzyciel (art. 29 ust. 1 ustawy o kosztach komorniczych).

Sytuacja wierzyciela byłaby dużo korzystniejsza, gdyby ustawodawca nie zdecydował się na uchylenie art. 823 k.p.c. stanowiącego podstawę do umorzenia postępowania $\mathrm{z}$ mocy samego prawa. Skutki prawne umorzenia postępowania $\mathrm{z}$ mocy samego prawa biegły $\mathrm{z}$ upływem roku od dnia dokonania ostatniej czynności egzekucyjnej, a w razie zawieszenia postępowania — od ustania przyczyny zawieszenia. Oznacza to, że jeśli roczny termin przewidziany w art. 823 k.p.c. upłynął $\mathrm{w} 2018 \mathrm{roku}$, to wraz $\mathrm{z}$ tą datą następowało umorzenie postępowania z mocy samego prawa, a co za tym idzie koszty tak umorzonego postępowania obciążyłyby dłużnika (art. 49 ust. 2 ustawy o komornikach sądowych i egzekucji), natomiast gdyby upływ rocznego terminu bezczynności wierzyciela upływał w roku 2019 to zgodnie z obecnymi unormowaniami koszty postępowania byłby zobowiązany uiścić wierzyciel (art. 29 ust. 1 ustawy o kosztach komorniczych).

59 I. Kunicki, Ustawa o kosztach komorniczych. Komentarz, Warszawa 2018, komentarz do art. 29.

60 A. Durda, op. cit., komentarz do art. 49, teza 4. Szerzej zob. J. Jagieła, Zasady..., s. 26-39. 
W wypadku umorzenia postępowania z mocy samego prawa organ egzekucyjny nie musiał wydawać postanowienia o umorzeniu postępowania egzekucyjnego, w takim wypadku nie mogłoby więc dojść do podejmowania czynności z nieuzasadnioną zwłoką.

Co istotne, sytuacja, która powstała w wyniku zmiany przepisów, nie pozostawia komornikowi wyboru, ponieważ wydając postanowienie o umorzeniu postępowania egzekucyjnego po 1 stycznia 2019 roku, musi on kosztami tego postępowania obciążyć wierzyciela (art. 29 ust. 1 ustawy o kosztach komorniczych).

Zamiast rozwiać wątpliwości, przepisy przejściowe tylko skomplikowały sytuację $^{61}$. Zgodnie bowiem z art. 52 ust. 1 i 2 ustawy o kosztach komorniczych do postępowań wszczętych i niezakończonych przed dniem wejścia w życie niniejszej ustawy stosuje się przepisy dotychczasowe, za wyjątkiem przepisów art. 29 i art. 30 ustawy o kosztach komorniczych, które stosuje się od dnia wejścia w życie ustawy, to jest od 1 stycznia 2019 roku. Przyjęcie tego typu unormowań oznacza w praktyce, że wyłącznie od daty wydania przez komornika postanowienia o umorzeniu postępowania egzekucyjnego zależy, która ze stron tego postępowania zostanie obciążona kosztami. Rodzi to dalsze konsekwencje w postaci konieczności dokonania oceny, czy umorzenie przez komornika postępowania egzekucyjnego w 2019 roku, mimo zaistnienia ku temu podstaw już w roku 2018 (co jest widoczne zwłaszcza wobec złożenia przez wierzyciela w 2018 roku wniosku o umorzenie postępowania), można uznać za czynność podjętą z nieuzasadnioną zwłoką, rodzącą odpowiedzialność dyscyplinarną komornika, a także czy tego typu zwłoka komornika może stanowić podstawę odpowiedzialności odszkodowawczej.

\section{NIEUZASADNIONA ZWŁOKA W UMORZENIU POSTĘPOWANIA EGZEKUCYJNEGO JAKO PRZEWINIENIE DYSCYPLINARNE}

Nowa ustawa o kosztach komorniczych, a w szczególności art. 52 ust. 2 tej ustawy, nie pozostawia wątpliwości, że wydanie przez komornika postanowienia o umorzeniu postępowania po 1 stycznia 2019 roku obliguje go - na podstawie art. 29 ustawy o kosztach komorniczych — do obciążenia kosztami umorzonego postępowania wierzyciela. Niezastosowanie się do przepisów przejściowych spowodowałoby narażenie Skarbu Państwa na straty, gdyż od dnia 1 stycznia 2019 roku opłata egzekucyjna stanowi nieopodatkowaną należność budżetową o charakterze publicznoprawnym pobieraną za czynności zgodnie $\mathrm{z}$ art. 149 ust. 1 ustawy o komornikach sądowych ${ }^{62}$. Stosownie do art. 150 ust. 1 i 2 ustawy o ko-

61 Szerzej M. Uliasz, op. cit., $1258 \mathrm{n}$.

62 De lege lata zmiana charakteru prawnego opłaty egzekucyjnej sprawiła, że komornik w każdym przypadku, także w razie niemożności jej poboru, obowiązany jest się rozliczyć. Zob. M. Klonowski, [w:] Ustawa .., komentarz do art. 149, teza 1. 
mornikach sądowych opłata egzekucyjna stanowi podstawę do obliczenia wynagrodzenia prowizyjnego proporcjonalnego do wysokości uzyskanych przez komornika opłat egzekucyjnych. Należy jednak zauważyć, że konieczność zastosowania art. 29 ustawy o kosztach komorniczych i obciążenia kosztami umorzonego postępowania wierzyciela, nie oznacza, że umorzenie przez komornika postępowania dopiero po 1 stycznia 2019 roku, mimo zaistnienia ku temu podstaw w 2018 roku, jest działaniem prawidłowym.

Zastanowienia wymaga, czy wobec zaistnienia przesłanek do umorzenia postępowania egzekucyjnego w roku 2018 wydanie przez komornika postanowienia o umorzeniu tego postępowania po 1 stycznia 2019 roku może stanowić podstawę odpowiedzialności dyscyplinarnej, a więc czy można to zakwalifikować jako czynność podjętą z nieuzasadnioną zwłoką?

Nie ulega wątpliwości, że wydanie przez komornika postanowienia o umorzeniu postępowania jest czynnością, którą stosownie do art. $760 \S 1^{1}$ k.p.c. ${ }^{63}$ powinien podjąć niezwłocznie, nie później jednak niż w terminie siedmiu dni od dnia otrzymania wniosku. Choć termin ten nie jest obwarowany sankcją, ma charakter instrukcyjny ${ }^{64}$, to doktryna stoi na słusznym stanowisku, że niepodjęcie przez komornika czynności w zakreślonym przez ustawodawcę terminie może stanowić podstawę odpowiedzialności dyscyplinarnej, jeśli podjęcie czynności nastąpiło z nieuzasadnioną zwłoką ${ }^{65}$. Jeśli zatem zaistniały podstawy do umorzenia postępowania wobec bezczynności wierzyciela, komornik powinien je umorzyć na podstawie art. $824 \S 1$ pkt 4 k.p.c. Podobnie gdy wierzyciel złożył wniosek o umorzenie postępowania egzekucyjnego (art. 825 pkt 1 k.p.c.). Z punktu widzenia interesów wierzyciela nie jest bez znaczenia, kiedy komornik tej czynności

63 Dodany ustawą z 22 marca 2018 roku o komornikach sądowych, Dz.U. z 2018 r. poz. 771. Obowiązującemu art. $760 \S 1^{1}$ k.p.c. odpowiadał art. 45a ustawy o komornikach sądowych i egzekucji. Zgodnie z jego brzmieniem, komornik podejmuje niezwłocznie, nie później jednak niż w terminie siedmiu dni od dnia otrzymania wniosku wierzyciela, czynności niezbędne do skutecznego przeprowadzenia egzekucji lub zabezpieczenia roszczenia. W literaturze uznawano, że naruszenie terminu $\mathrm{z}$ art. 45a u.k.s.e. może też stanowić o podstawie odpowiedzialności dyscyplinarnej komornika (art. 71 pkt 5 u.k.s.e.), przy czym do zaistnienia takiej odpowiedzialności przepis ten wymaga podejmowania czynności z rażącą zwłoką. Por. Z. Merchel, Ruchomość jako przedmiot egzekucji. Postepowanie. Wzory pism i orzeczeń, Warszawa 2006. De lege lata w miejsce rażącej zwłoki w art. 222 pkt 4 ustawy o komornikach sądowych jest mowa o nieuzasadnionej zwłoce. Oznacza to, że naruszenie przez komornika terminu instrukcyjnego do dokonania czynności może stanowić przewinie nie dyscyplinarne, jeśli podjęcie przez komornika czynności nastąpiłoby z nieuzasadnioną zwłoką.

64 Sędzia Sądu Najwyższego, Jacek Gudowski, zwraca uwagę, że od wejścia w życie ustawy z dnia 17 czerwca 2004 roku o skardze na naruszenie prawa strony do rozpoznania sprawy w postępowaniu przygotowawczym prowadzonym lub nadzorowanym przez prokuratora i postępowaniu sądowym bez nieuzasadnionej zwłoki postrzeganie terminów instrukcyjnych nabrało innego niż uprzednio znaczenia. Zob. J. Gudowski, [w:] Kodeks postępowania cywilnego. Koszty sądowe w sprawach cywilnych. Dochodzenie roszczeń w postępowaniu grupowym. Przepisy przejściowe. Komentarz do zmian, t. 2, red. T. Zembrzuski, Warszawa 2020, s. 1130.

65 Zob. między innymi R. Kowalkowski, op. cit., s. 69 n.; A. Marciniak, Opinia prawna..., s. 5 n.; M. Bieżuński, P. Bieżuński, op. cit., komentarz do art. 45a, teza 1. 
dokonał. Jeśli sześciomiesięczny termin uzasadniający umorzenie postępowania upłynął w roku 2018 lub też w 2018 roku wierzyciel domagał się umorzenia postępowania, to wydanie przez komornika postanowienia o umorzeniu postępowania dopiero w roku 2019 powodowało konieczność obciążenia wierzyciela kosztami postępowania egzekucyjnego.

Powstanie szkody po stronie wierzyciela nie jest przesłanką odpowiedzialności dyscyplinarnej komornika, z pewnością jednak jest czynnikiem motywującym stronę do zainicjowania postępowania dyscyplinarnego w obliczu konieczności zapłacenia opłaty stosunkowej, której wierzyciel mógłby uniknąć, gdyby komornik wydał postanowienie o umorzeniu postępowania bez nieuzasadnionej zwłoki ${ }^{66}$. Obciążanie wierzycieli opłatami egzekucyjnymi spowodowało składanie licznych skarg na czynności komorników. W skargach tych wierzyciele nie kwestionowali samego umorzenia postępowania egzekucyjnego, ale będące jego konsekwencją koszty tego postępowania (art. 29 ust. $1 \mathrm{w}$ zw. z art. 52 ust. 2 ustawy o kosztach). Jak wynika z orzecznictwa sądów powszechnych, komornicy w uzasadnieniu zaskarżonej czynności przekazywanym sądowi stosownie do art. 767 § k.p.c. wraz ze skargą na czynności komornika podnosili, że nadmiar pracy nie pozwolił im na umorzenie wszystkich postępowań egzekucyjnych przed końcem 2018 roku ze względu na liczbę złożonych przez wierzycieli wniosków o umorzenie postępowania ${ }^{67}$. $Z$ pewnością $z$ tych samych względów komornicy nie umorzyli również postępowań na podstawie art. $824 \S 1$ pkt 4 k.p.c. Jednak nadmiar pracy czy duża ilość złożonych przez wierzycieli wniosków o umorzenie postępowania nie sprawia, że czynność komornika w postaci wydania postanowienia nastąpiła bez jego winy, choćby nieumyślnej. Zawinione działanie (zaniechanie) komornika uzasadnia odpowiedzialność dyscyplinarną. Jeśli komornik wykazałby zaistnienie okoliczności wyłączających jego winę, to tym samym odpadłyby podstawy odpowiedzialności dyscyplinarnej.

Ustalenie, czy zwłoka komornika jest nieuzasadniona, a więc czy może stanowić podstawę odpowiedzialności dyscyplinarnej, każdorazowo wymaga zindywidualizowanego podejścia. Dokonując oceny działania komornika, należy rozstrzygnąć, czy w związku ze wzrostem liczby wniosków egzekucyjnych i po-

66 Uznanie komornika za winnego przewinienia dyscyplinarnego ułatwi wierzycielowi dochodzenie roszczeń odszkodowawczych. Szkoda wierzyciela równa się więc wysokości opłaty stosunkowej obliczonej na podstawie art. 29 ustawy o kosztach komorniczych, którą w wyniku nieuzasadnionej zwłoki komornika musi zapłacić wierzyciel.

67 W uzasadnieniu postanowienia Sądu Rejonowego Gdańsk-Południe w Gdańsku z 18 kwietnia 2019 roku, XII 1 Co 419/2019, LEX nr 2667274, podano, że w odpowiedzi na skargę na czynności komornika, ten ostatni zasygnalizował, że „w dniu 5 listopada 2018 roku do kancelarii zostało nadesłanych okokoło pięć tysięcy wniosków o umorzenie postępowania (każdy wniosek nadesłany został w oddzielnej kopercie), w tym także wnioski do spraw, które zostały przez komornika wcześniej umorzone bądź przekazane do innych organów egzekucji sądowej, po uprzednim wystosowaniu postanowienia o przekazaniu sprawy". Podobną argumentacją posłużył się komornik w odpowiedzi na skargę na czynności komornika rozpoznawaną przez Sąd Rejonowy w Tczewie. Zob. postanowienie Sądu Rejonowego w Tczewie z 22 marca 2019 roku, I Co 293/19, LEX nr 2638979. 
mimo dużego zaangażowania w pełnienie swoich obowiązków miał on obiektywną możliwość podjęcia czynności w terminie. W takim wypadku nie jest wystarczające samo stwierdzenie podejmowania czynności w postępowaniu egzekucyjnym z opóźnieniem, ale przede wszystkim konieczne jest zbadanie przez komisję dyscyplinarną okoliczności, które mają znaczenie przy kształtowaniu strony podmiotowej czynu. Komornik sądowy odpowiada bowiem dyscyplinarnie, ale za zawinione działanie lub zaniechanie, w tym także za nieuzasadnioną zwłokę w umorzeniu postępowania egzekucyjnego (art. 222 pkt 4 ustawy o komornikach sądowych). Komisja dyscyplinarna powinna więc zbadać charakter czynności i okres zaniechania. Zadaniem komisji jest dokonanie samodzielnych ustaleń, na ile zaniechanie komornika stanowi podejmowanie czynności z nieuzasadnioną zwłoką. Odpowiedzialność dyscyplinarna komornika sądowego nie jest uzależniona od wyrządzenia szkody stronie postępowania egzekucyjnego czy osobie trzeciej, jednak powstanie szkody, inne negatywne konsekwencje, motywy działania samego komornika, a więc szeroko rozumiana strona podmiotowa jego działania (zaniechania) mogą mieć wpływ zarówno na ocenę przewinienia dyscyplinarnego, jak i rodzaj orzeczonej kary. W sprawach dyscyplinarnych o tego typu przewinienia konieczne jest ustalenie zależności, które w sposób bezpośredni rzutują na treść określonego przewinienia dyscyplinarnego i wymierzenie odpowiedniej kary dyscyplinarnej.

\section{WNIOSKI}

Podsumowując dotychczasowe rozważania, warto przywołać jeden z argumentów podnoszony przez komornika sądowego w odpowiedzi na złożoną przez wierzyciela skargę na czynności komornika, a mianowicie: „Odnosząc się do zarzutu skarżącego na celowy brak podejmowania czynności zmierzających do umorzenia postępowania, a tym samym obciążenie wierzyciela opłatą egzekucyjną na podstawie art. 29 ust. 1 ustawy z dnia 28 lutego 2018 roku o kosztach komorniczych, wskazał, że przedmiotowa ustawa została ogłoszona dnia 25 kwietnia 2018 roku (Dz.U. z 2018 r. poz. 770). Wierzyciel powziął więc wiadomość, że ustawa wchodzi w życie z dniem 1 stycznia 2019 roku, jednakże z wnioskami o umorzenie postępowania wstrzymał się do listopada 2018 roku, jednocześnie podtrzymując prowadzenie egzekucji zgodnie z wnioskiem o wszczęcie postępowania "68.

Nie sposób nie zauważyć, że w wyniku zmiany przepisów wierzyciele zostali obciążeni kosztami postępowania egzekucyjnego, w stosunku do którego na etapie jego wszczynania obowiązywały zupełnie inne zasady rządzące rozdziałem kosztów. Nie można oczekiwać od wierzyciela, by śledził wszystkie zmiany legislacyjne i przewidywał, że postępowanie, które ma służyć wyegzekwowaniu

68 Por. uzasadnienie postanowienia Sądu Rejonowego Gdańsk-Południe w Gdańsku z 18 kwietnia 2019 roku, XII 1 Co 419/2019, LEX nr 2667274. 
od dłużnika świadczenia określonego w tytule wykonawczym zamiast prowadzić do spełnienia świadczenia, będzie generowało dla wierzyciela dodatkowe koszty, a więc de facto stratę. Nie można również wymagać od komornika, by śledząc na bieżąco liczne zmiany w przepisach, mógł przewidzieć konsekwencje w postaci masowych wniosków o umorzenie postępowania egzekucyjnego. Niestety nadmiar pracy czy choćby masowo składane przez wierzycieli wnioski o umorzenie postępowania egzekucyjnego nie usprawiedliwiają podejmowania przez komornika czynności z nieuzasadnioną zwłoką. Komornik może jednak uniknąć odpowiedzialności dyscyplinarnej, gdy podejmowanie przez niego czynności nawet ze znacznym opóźnieniem znajduje obiektywne uzasadnienie.

Analiza tytułowego zagadnienia prowadzi do wniosku, że komornicy sądowi ponoszą konsekwencje nieprzemyślanych zmian legislacyjnych. W tej sytuacji można zaproponować dwa rozwiązania. Pierwsze zakłada wobec bezczynności wierzyciela powrót do umorzenia z mocy samego prawa, co oznacza, że skutki prawne umorzenia postępowania egzekucyjnego powstają z chwilą upływu ustawowego terminu bez potrzeby wydawania przez komornika postanowienia. Jasne byłoby wówczas, którą ze stron postępowania egzekucyjnego należy obciążyć opłatą stosunkową. Drugim i, jak się zdaje, najprostszym rozwiązaniem byłoby uchylenie ust. 2 art. 52 ustawy o kosztach sądowych. W ten sposób, zgodnie z regułą jedności postępowania, do postępowań wszczętych i niezakończonych przed dniem wejścia w życie ustawy o kosztach komorniczych stosowałoby się w pełnym zakresie przepisy dotychczasowe. Zaletą drugiego rozwiązania jest również to, że odnosiłoby się ono zarówno do umorzenia postępowania wobec bezczynności wierzyciela, jak i do umorzenia na jego wniosek.

\section{COURT ENFORCEMENT OFFICER'S DELAY IN DISCONTINUING ENFORCEMENT PROCEEDINGS AS THE BASIS FOR DISCIPLINARY LIABILITY}

\section{Summary}

In the article devoted the delay of the court enforcement officer in discontinuing enforcement proceedings, the author analyses among others the impact of changing the nature of discontinuance of proceedings due to the creditor's inactivity on the risk of instituting disciplinary proceedings against a court bailiff. She also considers the extent to which the court enforcement officers themselves have the impact on the increase in disciplinary proceedings, and to what extent they bear the consequences of ill-considered legislative changes. To present the title issue, except for to discussing the grounds for discontinuing enforcement proceedings due to the creditor's inactivity (Civil Procedure Code Art.824 § 1 point 4) and at his request (Civil Procedure Code Art.825 point 1) in the previous and binding legal status and related costs, the article additionally summarizes the court enforcement officer's actions with unreasonable delay with the excessive length of the proceedings.

Keywords: unjustified delay, the court enforcement officer's action with unreasonable delay, discontinuance of enforcement proceedings, disciplinary proceedings 


\section{BIBLIOGRAFIA}

Bieniek G., Ciepła H., Dmowski S., Gudowski J., Kołakowski K., Sychowicz M., Wiśniewski T., Żuławska C., Komentarz do kodeksu cywilnego, ks. 3. Zobowiazania, t. 1-2, Warszawa 2011. Bieżuński M., Bieżuński P., Ustawa o komornikach sądowych i egzekucji. Komentarz, Warszawa 2010. Cieślak S., Formalizm postępowania cywilnego, Warszawa 2008.

Derlatka J., Zasada sprawnej egzekucji sądowej jest elementem efektywnego wymiaru sprawiedliwości, „Zeszyty naukowe Katolickiego Uniwersytetu Lubelskiego Jana Pawła II” 2017, nr 3.

Durda A., Ustawa o komornikach sądowych i egzekucji. Komentarz, Warszawa 2016.

Jagieła J., Wybrane zagadnienia dotyczace zawieszenia i umorzenia postępowania egzekucyjnego, „Problemy Egzekucji” 1999, nr 2.

Jagieła J., Zasady egzekwowania kosztów postępowania egzekucyjnego ustalonych przez komornika sądowego, „Przegląd Sądowy” 2015, nr 5.

Kłak C., Rozpatrzenie sprawy bez nieuzasadnionej zwłoki i skarga na przewlekłość postępowania. Zagadnienia wybrane, „Ius Novum” 2011, nr 2.

Kodeks karny. Komentarz, red. R. Stefański, Warszawa 2019.

Kodeks postępowania cywilnego. Koszty sądowe w sprawach cywilnych. Dochodzenie roszczeń w postepowaniu grupowym. Przepisy przejściowe. Komentarz do zmian, red. T. Zembrzuski, t. 2, Warszawa 2020.

Komentarz do ustawy o komornikach sqdowych, [w:] Ustawa o komornikach sadowych. Ustawa o kosztach komorniczych. Kodeks Etyki Zawodowej Komornika Sądowego. Komentarz, red. J. Świeczkowski, M. Świeczkowska-Wójcikowska, Warszawa 2020.

Komentarz do ustawy o komornikach sadowych, [w:] Ustawa o komornikach sadowych. Ustawa o kosztach komorniczych. Komentarz, red. M. Simbierowicz, M. Świtkowski, Warszawa 2019.

Konarska-Wrzosek V., Odpowiedzialność karna komornika sądowego, „Przegląd Prawa Egzekucyjnego" 2006, nr 12.

Korzan K., Sadowe postepowanie zabezpieczajace i egzekucyjne w sprawach cywilnych, Warszawa 1986.

Kowalkowski R., Czy komornik musi się obawiać odpowiedzialności dyscyplinarnej, gdy uchybi terminowi z art. 45 a ustawy o komornikach sądowych i egzekucji?, „Problemy Egzekucji” 2001, nr 18.

Kunicki I., Ustawa o kosztach komorniczych. Komentarz, Warszawa 2018.

Laszuk G., Postępowanie dyscyplinarne $w$ stosunku do komorników (Analiza praktyki w latach 1998-2005), Warszawa 2006.

Lubiński K., Nowelizacja ustawy o komornikach sądowych i egzekucji, „Problemy Egzekucji”2001, nr 18.

Marcewicz O., Streit-Browarna E., Zasada obowiązowego wszczęcia administracyjnego postępowania egzekucyjnego a zasada dyspozytywności w sądowym postępowaniu egzekucyjnym ujęcie prawnoporównawcze, „Studia Iuridica Lublinensia” 2016, nr 1.

Marciniak A., Opinia prawna na temat zasad egzekucyjnego zajęcia wierzytelności $w$ świetle przepisów ustawy z dnia 29 sierpnia 1997 r. o ochronie danych osobowych, ,Przegląd Prawa Egzekucyjnego" 2008, nr 1-2.

Marciniak A., Sadowe postępowanie egzekucyjne, Warszawa 2013.

Marciniak A., Ustawa o komornikach sądowych i egzekucji. Komentarz, Warszawa 2014.

May J., Odpowiedzialność dyscyplinarna komorników, [w:] Modele odpowiedzialności dyscyplinarnej zawodów prawniczych w Polsce i za granica, red. A. Brzezińska-Rawa, J. May, D. Sylwestrzak, Torun 2018.

Merchel Z., Opłaty egzekucyjne w sprawach eksmisyjnych, „Problemy Egzekucji” 2001, nr 14.

Merchel Z., Ruchomość jako przedmiot egzekucji. Postępowanie. Wzory pism i orzeczeń, Warszawa 2006. 
Olaś A., Umorzenie procesu cywilnego, Warszawa 2016.

Podrecka M., Zaspokojenie interesu wierzyciela przez zastępcze spetnienie świadczenia, „Kwartalnik Prawa Prywatnego" 1999, nr 1.

Rączka P., Odpowiedzialność dyscyplinarna komornika sądowego, „Przegląd Prawa Egzekucyjnego" 2006, nr 12.

Szczurek Z., [w:] Egzekucja sadowa w prawie polskim, red. Z. Szczurek, Sopot 2015.

Świeboda Z., Postępowanie zabezpieczające i egzekucyjne. Komentarz do części drugiej Kodeksu postępowania cywilnego, Warszawa 1994.

Świeczkowski J., [w:] Ustawa o komornikach sadowych i egzekucji. Komentarz, red. J. Świeczkowski, Warszawa 2012.

Świeczkowski J., Umorzenie postępowania egzekucyjnego na podstawie art. 823 k.p.c., „Gdańskie Studia Prawnicze" 26, 2011.

Świeczkowski J., Wystuchanie stron przed zawieszeniem lub umorzeniem postępowania egzekucyjnego, „Problemy Egzekucji” 2001, nr 13.

Ustawa o komornikach sądowych. Ustawa o kosztach komorniczych. Komentarz, red. R. Reiwer, Warszawa 2019.

Wengerek E., Postępowanie zabezpieczajace i egzekucyjne. Komentarz, Warszawa 1972.

Wengerek E., Sądowe postępowanie egzekucyjne w sprawach cywilnych, Warszawa 1970.

Winiarz J., [w:], Kodeks cywilny z komentarzem, red. J. Winiarz, Warszawa 1980.

Zedler F., Sadowe postępowanie egzekucyjne w orzecznictwie Trybunatu Konstytucyjnego w latach 1985-2008, [w:] Orzecznictwo Trybunału Konstytucyjnego a Kodeks postepowania cywilnego, red. T. Ereciński, K. Weitz, Warszawa 2010. 